\title{
Article \\ Life Cycle Assessment of Industrial Building Construction and Recovery Potential. Case Studies in Seville
}

\author{
Madelyn Marrero (), Cristina Rivero-Camacho, Alejandro Martínez-Rocamora *(D), \\ María Desirée Alba-Rodríguez (1) and Jaime Solís-Guzmán (1)
}

check for

updates

Citation: Marrero, M.;

Rivero-Camacho, C.;

Martínez-Rocamora, A.;

Alba-Rodríguez, M.D.; Solís-Guzmán,

J. Life Cycle Assessment of Industrial

Building Construction and Recovery

Potential. Case Studies in Seville.

Processes 2022, 10, 76. https://

doi.org/10.3390/pr10010076

Academic Editor: Dominic C. Y. Foo

Received: 24 November 2021

Accepted: 24 December 2021

Published: 30 December 2021

Publisher's Note: MDPI stays neutral with regard to jurisdictional claims in published maps and institutional affiliations.

Copyright: (C) 2021 by the authors. Licensee MDPI, Basel, Switzerland. This article is an open access article distributed under the terms and conditions of the Creative Commons Attribution (CC BY) license (https:// creativecommons.org/licenses/by/ $4.0 /)$.
ArDiTec Research Group, Department of Architectural Constructions II, Higher Technical School of Building Engineering, Universidad de Sevilla, Av. Reina Mercedes 4-a, 41012 Seville, Spain; madelyn@us.es (M.M.); crivero1@us.es (C.R.-C.); malba2@us.es (M.D.A.-R.); jaimesolis@us.es (J.S.-G.)

* Correspondence: rocamora@us.es

\begin{abstract}
In Spain, most businesses are medium to small size enterprises, representing $90 \%$ of the total, but there is a lack of studies of the types of building this sector uses. The main objective of this paper is to present a method for the evaluation of small industrial construction projects to facilitate the introduction of eco-efficient solutions. For this, it is necessary to identify the most representative buildings and the aspects of these which have the most environmental impact. A methodology in place for the evaluation of dwelling construction is adapted, for the first time, to evaluate industrial buildings. The construction solutions characterized are those traditionally used in the sector, as identified through 87 surveys. A standardized classification of work units is proposed to enable the use of environmental product information, such as eco-labels and/or EPD, and LCA databases. The carbon footprint (CF) and water footprint (WF) are the indicators selected because of their straightforward message. Finally, a comparative analysis is performed showing the high recycling potential of concrete and cement which, along with metals and aggregates, control the impact in terms of CF. With respect to the WF indicator, plastic substitute aggregates are among the materials with the greatest impact.
\end{abstract}

Keywords: recycling potential; industrial building; carbon footprint; water footprint; life cycle analysis

\section{Introduction}

The building sector contributes between 30 and $40 \%$ of the total $\mathrm{CO}_{2}$ emissions generated by society (European Parliament-Council of the European Union 2018). Regulation $305 / 2011$ concerning construction products promotes the assessment of the sustainable use of resources and the environmental impact of construction sites, and where available, recommends that environmental product declarations should be used. There are international standards in place to quantify these impacts by means of life-cycle assessment (LCA) (UNE-EN ISO 14040:2006; UNE-EN ISO 14044:2006; UNE-EN 15978:2012), environmental labels (UNE-EN ISO 14020:2002; UNE-EN ISO 14025:2006; UNE-EN 15804:2012; UNE-EN ISO 14021:2017), and the assessment of building life cycles (UNE-EN ISO 14001:2015; ISO 15686-5:2017). In the case of Spain, Royal Decree 187/2011 recognizes environmental product declarations (EPD) or Type III ecological labels in accordance with standard UNE-EN ISO 14025.

Sustainable urban development [1] is mainly focused on climate change and resource conservation, which can be applied to building construction, starting with material production and transport and continuing through construction activities and usage. Developers play a crucial role in change of the sector since they control purchasing and commissioning of construction products, and can lead environmental awareness, requiring ready access to environmental information [2]. 


\subsection{Industrial Building Assessment}

The assessment of the environmental impact of industrial buildings and prefabricated building elements has been explored by several authors, and a variety of indicators including carbon footprint, embodied energy or waste reduction have been reported. For example, researchers from the Basque Country in Spain proposed a method for the environmental analysis of industrial buildings through an integrated value model for sustainable assessment (MIVES) [3,4]. According to the authors, industrial buildings have been overlooked in life cycle analysis (LCA) studies which usually focus on residential and office buildings. Their approach follows an analytic hierarchical process (AHP) where several quantitative and qualitative aspects of the building are evaluated, transformed into a standard unit, and weighted according to the importance of each aspect. Bonamente and Cotana [5] conducted a systematic LCA of four prefabricated industrial buildings in Italy considering carbon footprint and primary energy consumption in a cradle-to-grave approach. Their calculation model was especially sensitive to modifications of the thermal insulation and expected service life as these influenced the embodied energy and carbon footprint of the construction phase, but more significantly the energy consumption during the use phase. Floor area and the foundation type had a lower influence on the results. Moreover, Tulevech et al. [6] carried out a LCA of a low-energy industrial building and a multi-scenario analysis that revealed significant energy-saving potential through a combination of recycling strategies and the installation of a rooftop PV system, which enabled zero life-cycle energy demand to be achieved.

Regarding the analysis of existing industrial buildings, Opher et al. [7] studied the life-cycle GHG emissions of the restoration of a heritage industrial building in Toronto, Canada, with particular interest in considering restrictions on the design related to the conservation of the building's external aesthetics. Their analysis included a cradle-to-grave LCA of construction materials, transport, and construction activities for the restoration process, as well as the foreseeable emissions due to operational energy consumption. The results showed that the embodied carbon footprint of the restoration project would be balanced by savings in operational energy within 3 to 13 years, depending on the energy sources used for heating, cooling, and lighting. Shubbar et al. [8] explored the potential energy savings of retrofitting an existing industrial building in Liverpool, UK, using IESVE (integrated environmental solutions virtual environment) software. They determined that installing wall and floor insulation could reduce energy consumption and carbon footprint by $56 \%$, which could be further improved by using PV panels.

Heravi et al. [9] highlighted the importance of the sustainability of industrial buildings in developing countries given their need for growth in industrial areas. In their study, they designed a holistic evaluation model of sustainability indicators including the environmental, social, and economic dimensions through the entire life cycle of petrochemical projects. Finally, they evaluated the correlation between variables and between the three dimensions of sustainability. Similarly, Židoniene and Kruopiene [10] proposed another life cycle assessment and environmental impact assessment framework for industrial buildings and applied it to a case study of an insulation materials production plant, enabling a $40 \%$ decrease of impact on human health and a $20 \%$ saving of primary resources compared to the initial situation.

In some instances, LCA studies focus on building systems or elements instead of complete buildings. For instance, Kovacic et al. [11] developed a life-cycle environmental and economic analysis tool to support decision-making on façade systems for industrial buildings. Through the assessment of three façade systems, they determined that the substantial differences in construction costs became less significant after 35 years of service life. Regarding the environmental dimension, cross-laminated timber was predicted to produce $80 \%$ less emissions than steel-liner tray and sandwich panels. Švajlenka et al. [12] analyzed the environmental impact of different construction systems of buildings for agricultural production through a cradle-to-gate LCA method. Again, wood-based systems obtained the best results in comparison to steel- and reinforced-concrete-based solutions. Aye et al. [13] 
analyzed the life-cycle greenhouse gas (GHG) emissions and energy consumption of prefabricated reusable building modules. The assessment of an 8-storey building revealed that a steel-structured prefabricated system could reduce material consumption by up to $78 \%$ compared to a conventional concrete system, while this resulted in a $50 \%$ increase in embodied energy. The authors highlighted the benefits of reusing these materials for reduction of both the space needed for landfill and the requirement for primary resources. This reuse of materials produced significant embodied energy savings for the construction of a new system ( $81 \%$ for steel and $69 \%$ for timber systems over concrete), as well as reduction in the consumption of primary material resources. In terms of WF, plastics are the most important category, followed by wooden materials, even though both materials are not significant in terms of weight.

Regarding construction and demolition waste, Begum et al. [14] compared conventional and industrialized building systems in terms of waste generation and recycling potential. The study revealed that prefabrication resulted in significant reduction in waste generation, while the rates of reused and recycled waste materials were relatively higher than in conventional construction. The waste reduction potential of prefabricated elements was also explored by Jaillon et al. [15] through a survey of experienced professionals and several case studies of residential buildings in Hong Kong, and by Li et al. [16], who developed a calculation model for the benefits of prefabrication in construction where they integrated all waste handling activities, and validated it through a case study in Shenzhen, China. Furthermore, the latter showed that granting subsidies to promote the use of prefabrication was a more effective strategy than increasing taxes on waste generation. Recently, Lu et al. [17] carried out a new quantitative analysis to re-evaluate the effects of prefabrication on the minimization of construction and demolition waste based on big data obtained from 114 high-rise building projects in Hong Kong, mostly residential, with 85 of them applying prefabrication and 29 conventional construction. Their study revealed that prefabrication could reduce waste generation by $15.38 \%$ compared to conventional construction, with precast windows and walls playing a major role in this. Finally, Mah et al. [18] estimated that moving to prefabricated industrial building systems would reduce the impact on landfill of construction and demolition waste by $98.1 \%$, while continuing with the business-as-usual landfilling model from now to 2025 would increase this impact by $20.2 \%$.

\subsection{Life Cycle Assessment of Architectural Projects and Construction Materials}

At the material manufacturing level, environmental product declarations (EPDs) incorporate the LCA inventory of products and assess the use and efficiency of material resources [19]. This information can be employed as a contracting criterion [20,21], as described in the Spanish Law of Public Sector Contracts (LPSC) [22], which establishes a contracts framework that includes economic, environmental and social criteria. The green public procurement concept was also incorporated into Spanish legislation in 2019 with environmental policies related to climate change, resource use, and sustainable production and consumption [23]. The latter establishes sustainability requirements for transport, road construction, design and construction of offices, food, etc.

In Spain, there are tools in place for the assessment of projects, such as BREEAM (Building Research Establishment Environmental Assessment Methodology) [24] and LEED (Leadership in Energy and Environmental Design) [25]. Other available tools are ECOMETRO (carbon footprint metric in construction) [26], BEDEC cost database (database of construction cost in Catalunya) [27], SOFIAS (Software for a Sustainable Architecture) tool [28], and E2CO2Cero (embodied energy and zero $\mathrm{CO}_{2}$ tool) [29], which calculate $\mathrm{CO}_{2}$ emissions through the project bill of quantities. However, these are not generally employed in Spain, mainly due to the expertise needed for their management and their expensive implementation due to user license payments. Open data can be employed for LCA information, such as free access construction cost databases and EPDs, which can reduce the assessment costs. There are also opportunities to include other indicators, apart from the 
calculation of $\mathrm{CO}_{2}$ emissions, and to identify those activities that actually control a variety of impacts [30].

In Spain, most businesses are medium to small size enterprises located in industrial buildings. These buildings are usually small [31], with less than 20 employees. For example, in 2014, according to the last report available by the National Institute of Statistics of Spain, these represented $90 \%$ of the total number of enterprises. Despite this high representation of small industrial buildings in this sector, very few studies have focused on determining their environmental impact.

\subsection{The Proposal}

The present paper presents a methodology for the evaluation of industrial construction projects in Spain. For this, it is necessary to identify the most representative buildings and the most impacting elements of the projects. A methodology that evaluates urbanization, gardens and dwelling construction is adapted, for the first time, for the assessment of industrial buildings. The constructive solutions are those traditionally used in the sector, as identified through surveys. A standardized classification of work units is proposed to introduce the environmental product information. The carbon footprint $(\mathrm{CF})$, water footprint (WF), the generation of construction and demolition waste (CDW) and its recyclability potential are the indicators selected because of their straightforward message. Finally, in the province of Seville, a comparative analysis of the most characteristic industrial building typologies, identified from an 87-buildings sample of industrial projects, is performed.

\section{Materials and Methods}

As can be seen in Figure 1, the methodology commences with the collection of accessible and generic data from construction cost and LCA databases. This information can be tailored to the project specifics, the project bill of quantities and environmental product information, such as that obtained for the specific materials and products from eco-labels, self-declarations and EPDs. Each element that is part of the project budget is assessed in terms of WF and CF, generating an "environmental budget", similar to that previously defined for the calculation of the ecological footprint [32]. These two environmental impacts have also been assessed in other type of projects [33] and in CDW management [34]. Finally, surveys are defined that include a new classification of works and construction characteristics in the province of Seville, and three representative projects are fully evaluated.

\subsection{Work Units Classification}

The automation of data and its processing constitute advances in information technology (IT) that provide major advantages. The most representative classification systems of construction information, in order of publication, are: MasterFormat [35], CI/SfB [36], the Standard Method of Measurement of Civil Engineering [37], Uniformat [38], and Uniclass [39]. In Spain, the construction classification systems are related to cost control and are region specific, such as the Institute of Construction Technology of Catalonia [27] and the Andalusian Construction Cost Database (ACCD) [40].

The ACCD [41], published from 1986 to the present, is a database classification [40] with a pyramidal structure (see Figure 2). The base of the pyramid is supplier costs which represents the actual market. The next ascending level is basic costs (BC), which are of three types, materials, labor and machinery. The next higher level, the auxiliary costs (AC) are combinations of $\mathrm{BC}$, while work units are represented above this by unit costs (UC) composed of BC and/or AC. UC are grouped in chapters corresponding to the stages of the construction process, such as earthworks, foundation, structure, etc. At the top of the pyramid are the costs that are not part of the activities of the construction site, including industrial profit, taxes, and overheads. 


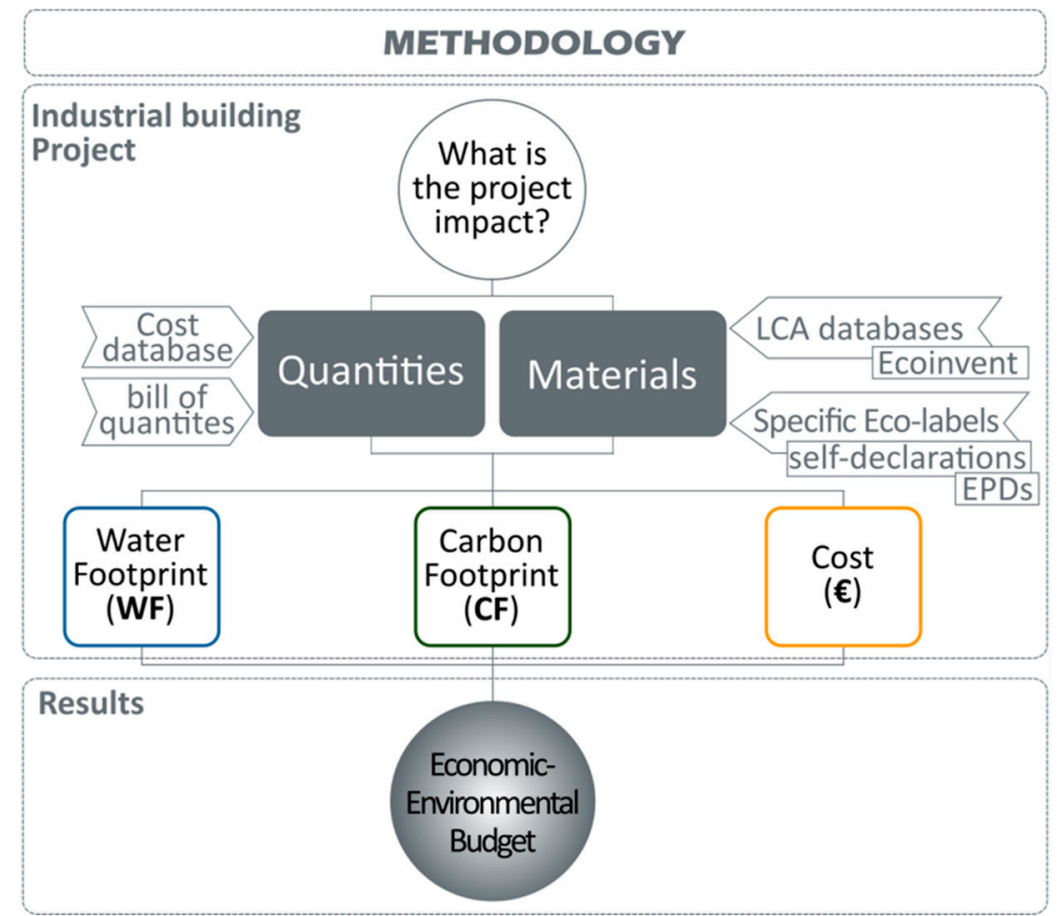

Figure 1. Methodology for the inclusion of the $\mathrm{WF}\left(\mathrm{m}^{3}\right.$ water $)$ and $\mathrm{CF}\left(\mathrm{tCO}_{2} \mathrm{eq}\right)$ in the green assessment of industrial projects.
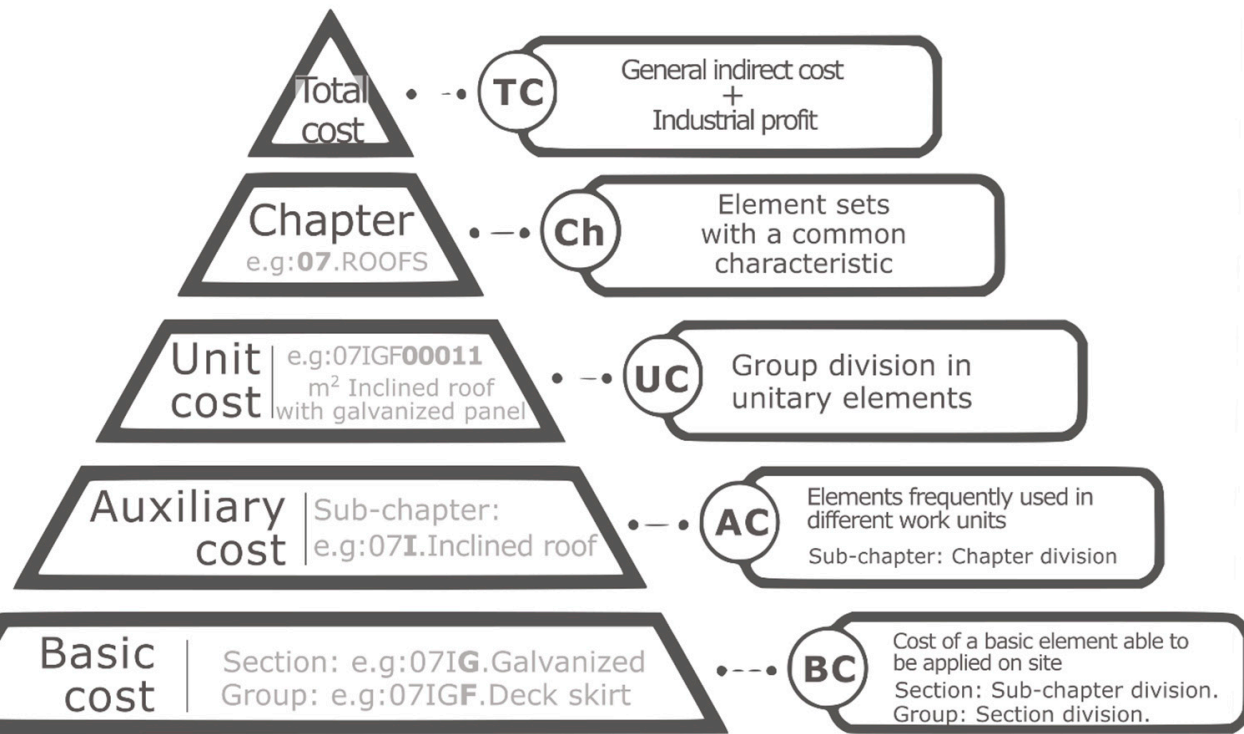

Figure 2. Hierarchical pyramid of the ACCD (adapted from [42]).

\subsection{Environmental Analysis}

Several tools and calculation models are available to determine the environmental impact of construction. These can be based on multi-variable analysis, such as the ecological footprint, energy, CML, or Eco-indicator, or use one indicator, such as CF or WF [43]. The CF indicator is commonly used in construction work assessment [44-46], and improvements have taken place in the definition of $\mathrm{CO}_{2}$ ranges in manufacturing [47]. The WF, another indicator with a straightforward message [48,49], is defined by the water footprint network [50] and determines the amount of water consumed in the production of goods, employing the standard calculation methodology [51] and using The Water Footprint As- 
sessment Manual [52]. The combination of indicators has produced interesting comparative results in previous work by the authors [33,34].

CF and WF information can be obtained from LCA databases of construction products [53] and EPDs (www.eco-platform.org/ accessed on 15 December 2021) [54]. The consumption of natural resources on site is mainly due to energy consumption by machinery (fuel or electricity), and construction material expenditure (e.g., during manufacture, transport, and commissioning).

\section{Machinery}

The machinery environmental impact is due to the energy consumption during its operation on the construction site (differentiating between fuel and electrical energy). Fuel consumption depends on the engine power and working hours, differentiating between diesel and petrol. The $\mathrm{CO}_{2}$ generated by one liter of fuel is used [55] as an emission factor in Equation (1). The $\mathrm{CO}_{2}$ emissions corresponding to the Spanish electrical system [56] are used for electrical machinery on site (see Equation (2)). The WF of electricity consumption is obtained from the embodied water in energy generation according to LCA databases.

\section{Building materials}

The environmental impact of materials, following a cradle-to-gate model, can be obtained from EPDs or LCA databases. Their transport to the construction site depends on the type of products [32]: for concrete, the truck capacity is $24,000 \mathrm{~kg}$ and $20 \mathrm{~km}$ trip and for the other products it is $2000 \mathrm{~kg}$ and $250 \mathrm{~km}$ trip. The diesel consumption is $26 \mathrm{~L} / 100 \mathrm{~km}$ and its emissions are $2.62 \times 10^{-3} \mathrm{tCO}_{2} / \mathrm{L}$ [57]. The diesel embodied water is $1.26 \mathrm{~m}^{3} / \mathrm{L}$, and the electric mix embodied energy is 3.6 MJ/kWh in Spain (see Equations (1) and (2)).

The volume of each construction element is determined using technical data and commercial product descriptions as BC have typical measurement units in the market $\left(\mathrm{m}^{3}\right.$, $\mathrm{m}^{2}$, meters, tons, thousands of units, etc.) not always expressed in $\mathrm{kg} \mathrm{or} \mathrm{m}^{3}$. Once the volume is calculated, the elements' densities, according to the Catalogue of Construction Solutions of the Technical Building Code [58] and the Spanish Technical Building Code [59] are used to calculate the mass, as shown in Table 1.

Table 1. Weight calculation of basic construction elements.

\begin{tabular}{|c|c|c|c|c|c|c|c|c|c|}
\hline \multirow{2}{*}{$\begin{array}{l}\text { ACCDC } \\
\text { ode }\end{array}$} & \multirow{2}{*}{$\begin{array}{c}\text { Cost } \\
(€)\end{array}$} & \multirow{2}{*}{ Unit } & \multirow{2}{*}{ Description } & \multicolumn{3}{|c|}{ Volume $\left(\mathrm{m}^{3}\right)$} & \multirow{2}{*}{$\begin{array}{l}\text { Density } \\
\left(\mathrm{kg} / \mathrm{m}^{3}\right)\end{array}$} & \multirow{2}{*}{$\begin{array}{l}\text { Weight } \\
\text { (kg) }\end{array}$} & \multirow{2}{*}{ Source } \\
\hline & & & & $x$ & $\mathrm{Y}$ & $\mathbf{Z}$ & & & \\
\hline AG00100 & 10.86 & $\mathrm{~m}^{3}$ & Gravel & 1.00 & 1.00 & 1.00 & 1784.00 & 1784.000 & [58] \\
\hline CA80030 & 3.78 & $\mathrm{~kg}$ & Steel triangular section mesh & 1.00 & 1.00 & 1.00 & 1.00 & 1.000 & [58] \\
\hline CH80200 & 157.08 & $\mathrm{~m}^{3}$ & Light concrete- $25 \mathrm{~N} / \mathrm{mm}^{2}$ & 1.00 & 1.00 & 1.00 & 2549.25 & 2549.250 & [59] \\
\hline FB80200 & 2.14 & $\mathrm{u}$ & Concrete block $50 \times 20 \times 25 \mathrm{~cm}$ & 0.50 & 0.20 & 0.25 & 900.00 & 22.500 & [58] \\
\hline IE02600 & 4.43 & $\mathrm{~m}$ & $\begin{array}{c}\text { Copper wire } 1 \times 16 \mathrm{~mm}^{2} \\
\text { H07V-K(AS) }\end{array}$ & 1.00 & 16.00 & $10^{-6}$ & 880.00 & 0.0141 & [58] \\
\hline PA00500 & 1.71 & $\mathrm{Kg}$ & Acrylic paint & 1.00 & 1.00 & 1.00 & 1.00 & 1.000 & [58] \\
\hline QP00800 & 3.99 & $\mathrm{~m}$ & $\begin{array}{l}\text { Sheet flashing for sandwich panel. } \\
\text { Polyester }\end{array}$ & 1.00 & 0.50 & 0.005 & 1140.00 & 2.085 & [59] \\
\hline QP02000 & 22.70 & $\mathrm{~m}^{2}$ & Sandwich panel $30 \mathrm{~mm}$ polyester & 1.00 & 1.00 & 0.03 & 1223.64 & 36.709 & [59] \\
\hline RA00300 & 0.17 & $\mathrm{u}$ & Soft solid color tile $15 \times 15 \mathrm{~cm}$ & 0.15 & 0.15 & 0.01 & 2300.00 & 0.518 & [58] \\
\hline WW00300 & 0.55 & $\mathrm{u}$ & Special small material & 0.10 & 0.005 & 0.005 & 8004.65 & 0.020 & [59] \\
\hline
\end{tabular}

The LCA data is obtained from the Ecoinvent database [60], which was established by the Swiss Centre for Life Cycle Inventories and applied in Simapro. It is chosen because it combines several databases of construction materials [53]. Finally, BC are grouped into "environmental families". The environmental impact of machinery is obtained by applying Equations (1) and (2) depending on the energy source of each machine, while that of construction materials is obtained through Equation (3).

$$
\mathrm{IM}_{\mathrm{COMB}}=\mathrm{P} \times \mathrm{TU} \times \mathrm{Per} \times \mathrm{IU}_{\mathrm{COMB}},
$$


where P: power of the engine $(\mathrm{kW})$; TU: time of use (h); Per: performance as liters of diesel or petrol consumed per unit of engine power $(1 / \mathrm{kWh})$; and IU $\mathrm{COMB}_{\mathrm{B}}$ : unit impact of diesel or petrol $\left(\mathrm{MJ} / \mathrm{L}, \mathrm{tCO}_{2} \mathrm{eq} / \mathrm{L}, \mathrm{m}^{3}{ }_{\text {water }} / \mathrm{L}\right)[61]$.

$$
\mathrm{IM}_{\mathrm{ELEC}}=\mathrm{P} \times \mathrm{TU} \times \mathrm{IU}_{\mathrm{ELEC}},
$$

where $\mathrm{IU}_{\mathrm{ELEC}}$ : unit impact of electric $\operatorname{mix}\left(\mathrm{MJ} / \mathrm{kWh}, \mathrm{tCO}_{2} \mathrm{eq} / \mathrm{kWh}, \mathrm{m}^{3}{ }_{\text {water }} / \mathrm{kWh}\right)[50,62]$.

$$
\mathrm{I}_{\mathrm{MAT}}=\left(\Sigma \mathrm{i} \mathrm{Cm}_{\mathrm{i}} \times \mathrm{IU}_{\mathrm{MAT}}\right)+\left(\mathrm{IU}_{\mathrm{TRAN}} \times \mathrm{Cm}_{\mathrm{i}}\right),
$$

where $\mathrm{IU}_{\mathrm{MAT}}$ : unit impact of manufacturing per $\mathrm{kg}$ of material $\left(\mathrm{MJ} / \mathrm{kg}, \mathrm{tCO}_{2} \mathrm{eq} / \mathrm{kg}\right.$, $\mathrm{m}^{3}{ }_{\text {water }} / \mathrm{kg}$ ); IU $\mathrm{IRAN}_{\text {TR }}$ unit impact of transport per $\mathrm{kg}$ of material $\left(\mathrm{MJ} / \mathrm{kg}, \mathrm{tCO}_{2} \mathrm{eq} / \mathrm{kg}\right.$, $\mathrm{m}^{3}{ }_{\text {water }} / \mathrm{kg}$ ); and $\mathrm{Cm}_{\mathrm{i}}$ : consumption of construction material $i(\mathrm{~kg})$.

The life cycle inventory (LCI) for the CF of each material, is obtained using the IPCC 100 yr methodology, which isolates $\mathrm{CO}_{2}$ and other $\mathrm{GHGs}$ in $\mathrm{tCO}_{2} \mathrm{eq} / \mathrm{kg}$. Calculation of the WF is based on the work of Hoekstra et al. [51,52,63], that represents the direct and indirect consumption in $\mathrm{m}^{3}$ water $/ \mathrm{kg}$. Figure 3 summarizes the methodology, which combines the construction cost systematic classification of the work with the environmental impact.

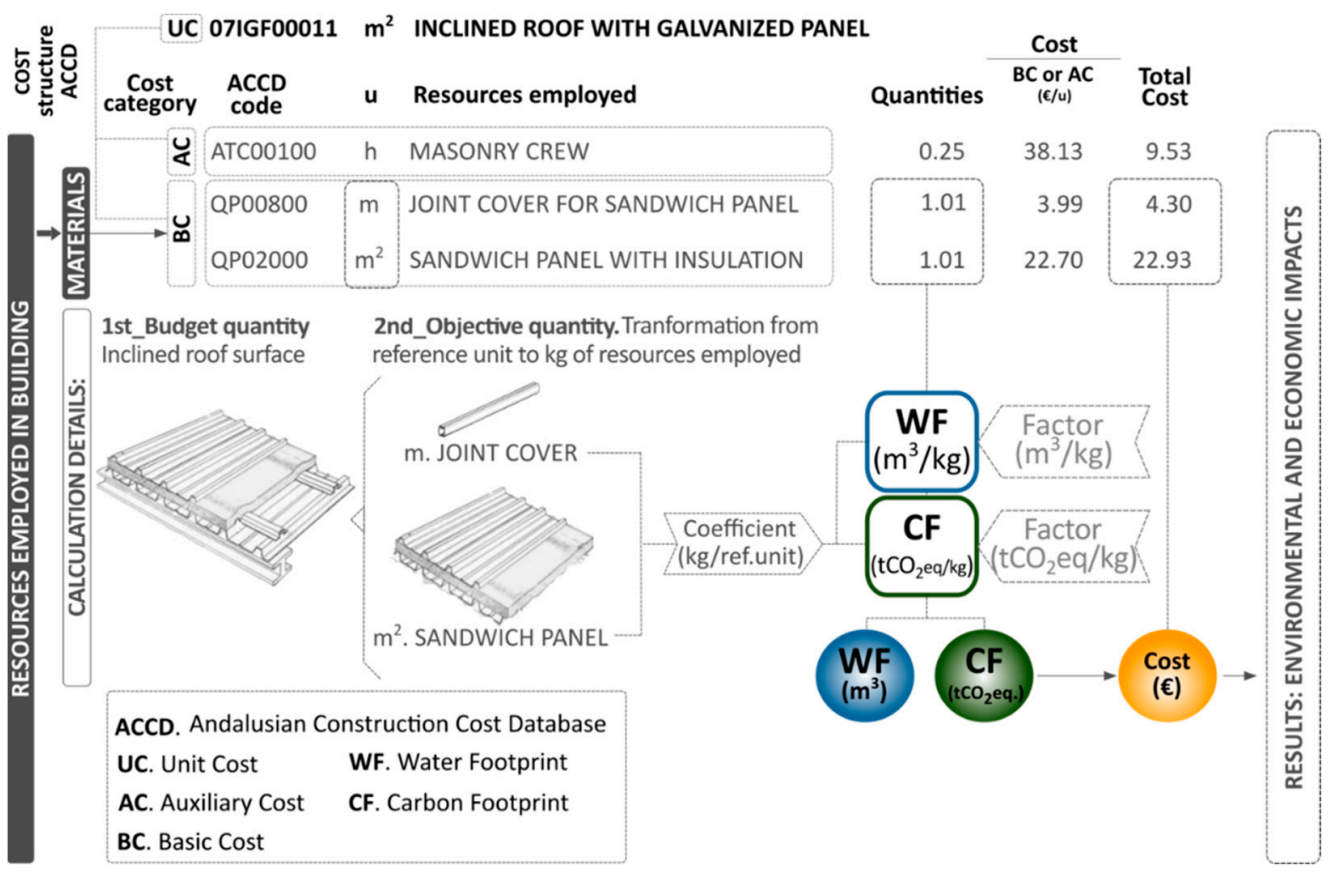

Figure 3. The industrial building unit is transformed into environmental impact per work unit.

\section{Construction and demolition waste (CDW)}

The construction materials that generate waste due to losses, cuts, damaged pieces, demolition and three transformation coefficients [64] are defined for calculation, as expressed in Equation (4):

$$
\mathrm{QRi}=\mathrm{Qi} \times \mathrm{CRi} \times \mathrm{CCi} \times \mathrm{CTi},
$$

where $\mathrm{QR}_{\mathrm{i}}$ : amount of waste generated by element or material i; Qi: quantity of material i in project; $\mathrm{CRi}$ : percentage of the original element wasted; $\mathrm{CC}_{\mathrm{i}}$ : conversion factor of the units of the original element or product to the units of waste $\left(t, \mathrm{~m}^{3}, \mathrm{~kg}\right.$, or unit); and $\mathrm{CT}_{\mathrm{i}}$ : considers the change in volume of material $\mathrm{i}$ when it is transformed into waste (Figure 4). 


\begin{tabular}{|c|c|c|c|c|}
\hline \multicolumn{5}{|c|}{\begin{tabular}{|l|l|l|}
$07 I G F 00011$ & $\mathrm{~m}^{2}$ INCLINED ROOF WITH GALVANIZED PANEL \\
\end{tabular}} \\
\hline \multicolumn{5}{|c|}{$\begin{array}{l}\text { Inclined roof with skirt of insulating panel of sandwich type sheet ( } 30 \mathrm{~mm} \text { thick), formed by } \\
\text { two galvanized steel sheets } 0.5 \mathrm{~mm} \text { thick and internally filled by injection with rigid } \\
\text { polyurethane foam (density } 40 \mathrm{~kg} / \mathrm{m}^{3} \text { ), including } 0.7 \mathrm{~mm} \text { thick flashing. }\end{array}$} \\
\hline \multicolumn{5}{|c|}{ Measured in true magnitude deducting gaps greater than $1 \mathrm{~m}^{2}$} \\
\hline CODE & CONCEPT & Q & $\operatorname{cost}$ & AMOUNT \\
\hline ATC00100 & h MASONRY CREW & 0.25 & 38.13 & 9.53 \\
\hline QP00800 & m JOINT COVER FOR SANDWICH PANEL & 1.01 & 3.99 & 4.03 \\
\hline QP02000 & $\mathrm{m}^{2}$ SANDWICH PANEL WITH INSULATION & 1.01 & 22.70 & 22.93 \\
\hline WW00300 & u COMPLEMENTARY MATERIAL & 1.00 & 0.55 & 0.55 \\
\hline WW00400 & u SMALL MATERIAL & 1.00 & 0.30 & 0.30 \\
\hline & & & TOTAL & 37.34 \\
\hline
\end{tabular}

\section{Calculation details}

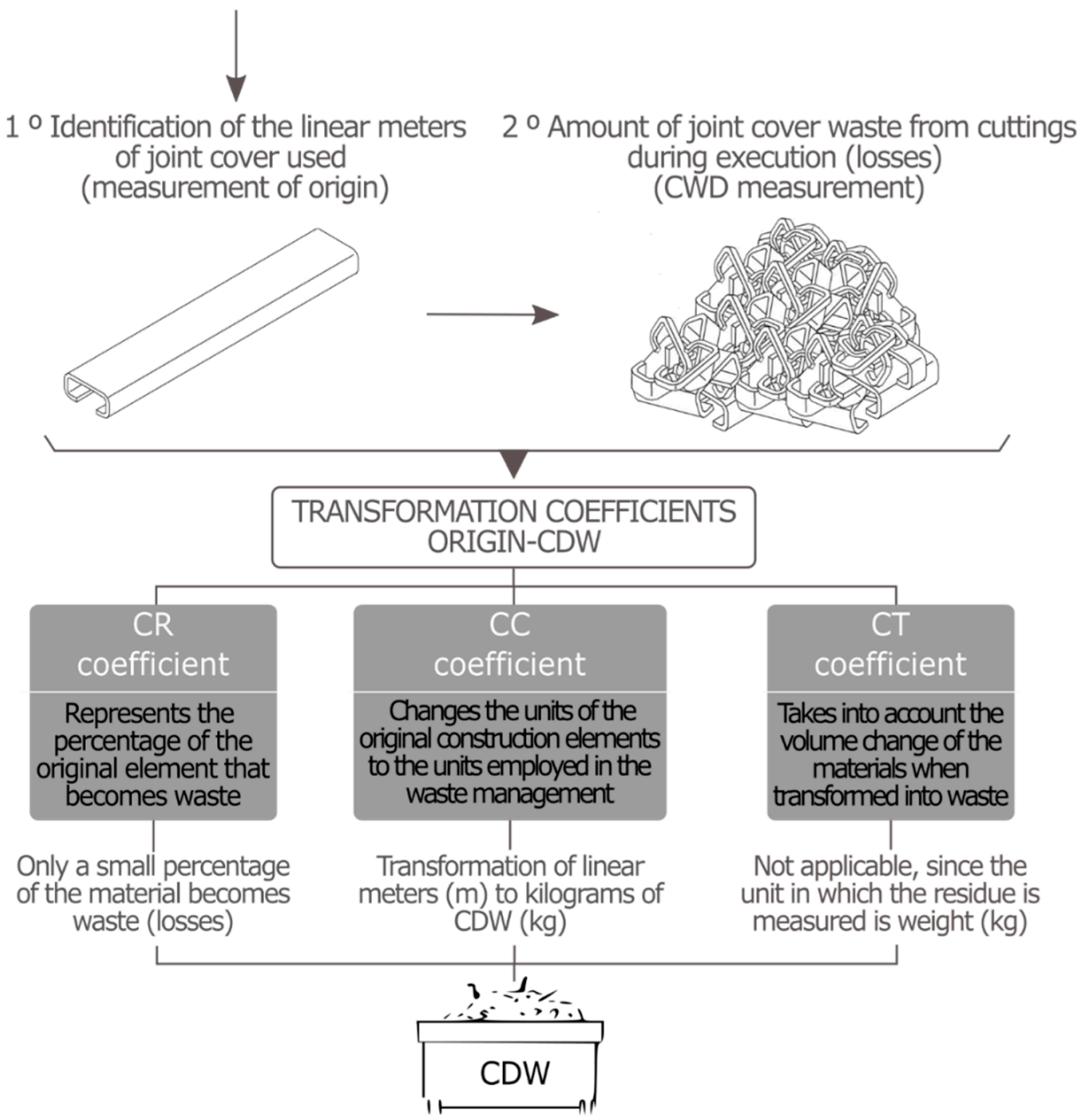

Figure 4. Example of unit cost of chapter roof and the calculation of CDW using the transformation coefficients.

Table 2 shows examples of these coefficients used in the construction of industrial buildings. This methodology has been explained more fully by Marrero et al. [65]. For example, for joint cover (Figure 4), the CR coefficient is 0.01 because only $1 \%$ is lost due to cuttings during the execution; $\mathrm{CC}$ is equal to 2.00 because the unit of measurement of the element is its length in meters, and one meter of cover weights $2 \mathrm{~kg}$; finally, CT is equal to 1.00 as this coefficient considers the change in volume of the material from the origin to its destination as waste, but in this case the unit of waste management is also kilograms. The 
CDW management cost is obtained by applying the corresponding cost in the ACCD for each type of waste depending on its destination/treatment.

Table 2. Transformation coefficients for an industrial building construction (examples defined in the present work).

\begin{tabular}{|c|c|c|c|c|c|}
\hline Constructive Element & Waste Origin & Waste Generated & CR & $\mathrm{CC}$ & CT \\
\hline \multirow{3}{*}{ Sandwich panel for cover } & Sandwich panel & Losses & 0.01 & 0.367 & 1.00 \\
\hline & Wooden & Packaging & 0.05 & 9.380 & 1.00 \\
\hline & Plastic & Packaging & 1.00 & 0.006 & 1.00 \\
\hline Steel $(\mathrm{kg})$ & Steel & Losses & 0.01 & 0.001 & 1.00 \\
\hline \multirow{3}{*}{ Paint (kg) } & Container & Packaging & 1.00 & 0.035 & 1.00 \\
\hline & Wooden & Packaging & 0.05 & 0.00025 & 1.00 \\
\hline & Plastic & Packaging & 1.00 & $1.28 \times 10^{-5}$ & 1.00 \\
\hline \multirow{2}{*}{ Lighting circuit (m) } & Copper & Losses & 0.05 & 0.829 & 1.00 \\
\hline & Wood & Packaging & 0.05 & 0.001 & 1.00 \\
\hline Earth excavation $\left(\mathrm{m}^{3}\right)$ & Soil & Excavation & 1.00 & 1.000 & 1.25 \\
\hline Join cover of roof & Plastic & Losses & 0.01 & 2.000 & 1.00 \\
\hline \multirow{2}{*}{ High-density polyethylene water pipe } & HDPE & Losses & 0.05 & 0.00213 & 1.00 \\
\hline & Sand & Losses & 0.01 & 0.065 & 1.00 \\
\hline Reinforced concrete & Concrete & Losses & 0.05 & 1.000 & 1.00 \\
\hline
\end{tabular}

\section{Case Studies}

\subsection{RecoverIND Project}

Access to and assessment of environmental information can be achieved through teaching tools for technicians, engineers and architects. The main objective of the European project RecoverIND, funded in the Erasmus+ 2020 call, is the transfer of knowledge, through the implementation of training tools at professional, vocational and higher education levels, on the use of new technologies that allow the rapid acquisition of data in the sector, with a wide range of applications in the construction industry, renovation and energy efficiency of buildings. Another important objective of the project is to facilitate the evaluation of industrial buildings' life cycle and identify better economic or environmental alternatives. The project is developing an open educational resources (OER) platform for students, teachers, researchers, and enterprises, to gain knowledge on environmental impact estimation methods. The main page of the official website shown in Figure 5 [66]. The circle represents the main objective to be tackle by RecoverIND, clockwise from top: teaching innovation, industry, material transport, construction, waste management, recycling potential and digitalization in the life cycle of industrial buildings. In this connection, the present article explores a simple methodology for the environmental assessment of industrial buildings. In the next sections, the evaluation of the sustainability of industrial budlings, using case studies, and tools in place for the assessment are presented.

\subsection{Actual Projects}

The case studies belong to Los Alcores, a supra-municipal entity that includes Seville capital and municipalities in Los Alcores area. Among its responsibilities is the management of CDW. It serves a population of approximately one million inhabitants. A statistical study was carried out to typologically assess the industrial buildings.

The study comprised the following:

1. Classification of industrial buildings based on specific construction criteria of the buildings. This included the following as the most important aspects: (industrial) use, number of floors, foundation, structure, roof, roof support, envelope, height and wall-to-wall width. 
2. Performing the survey. The surveys were carried out to obtain the characteristics and quantities $(Q)$ of work. Each survey was divided into two parts: the first was aimed at identifying the project according to the typology and the period in which it was carried out; the second collected the values of each of the different concepts into which each system is divided. This was organized according to a new classification model based on the ACCD [41], which can be found in Table A1 in Appendix A. Based on the economic budget, the survey gathered data on the amount of each construction element (in its corresponding unit) per $\mathrm{m}^{2}$ of floor area (see Table 3 ).

3. Analysis of the construction typologies of industrial buildings. The survey study was carried out in three municipalities of Los Alcores. A total of 87 industrial buildings were studied, 28 in Alcalá, 29 in Carmona and 30 in Mairena del Alcor.

4. Obtaining average statistical values of each construction element per $\mathrm{m}^{2}$ of floor area for the identified as most representative building typologies. These average values are obtained from the interquartile range of $75 \%$, to eliminate discordant extreme values.

Table 3. Description of case studies.

\begin{tabular}{|c|c|c|c|}
\hline & Project N1 & Project N2 & Project N3 \\
\hline \multicolumn{4}{|l|}{ LOCALIZATION } \\
\hline Municipality & Carmona & Alcalá de Guadaira & Mairena del Alcor \\
\hline Plastic & Seville & Seville & Seville \\
\hline Community & Los Alcores & Los Alcores & Los Alcores \\
\hline \multicolumn{4}{|l|}{ DIMENSIONS } \\
\hline Floor area $\left(\mathrm{m}^{2}\right)$ & 673.88 & 464.45 & 787.90 \\
\hline Number of floors & 1 & 1 & 1 \\
\hline Total height of building $(\mathrm{m})$ & 7.90 & 8.84 & 7.50 \\
\hline Total width of building (m) & 20.00 & 10.00 & 30.10 \\
\hline CONSTRUCTIVE FEATURES & $\begin{array}{l}\text { Heavy slab, continuous } \\
\text { trench, metal structure, } \\
\text { heavy enclosure executed on } \\
\text { site with concrete blocks and } \\
\text { sloping sheet metal in roof. }\end{array}$ & $\begin{array}{l}\text { Heavy slab, insulated footing, } \\
\text { concrete structure, precast } \\
\text { enclosure, and sloping roof } \\
\text { with sandwich panel. }\end{array}$ & $\begin{array}{l}\text { Semi-heavy slab, piles, metal } \\
\text { structure, precast enclosure, } \\
\text { and sloping roof with precast } \\
\text { panels. }\end{array}$ \\
\hline \multicolumn{4}{|l|}{ IMAGES } \\
\hline \multicolumn{4}{|l|}{ Exterior } \\
\hline Interior & & & \\
\hline
\end{tabular}

The most representative typologies were: typology 1 (one floor, precast enclosure and heavy slab), with 15 buildings analyzed; typology 2 (one floor, precast enclosure and semiheavy slab), with 29 buildings; and typology 3 (one floor, in-situ enclosure and heavy slab), with 15 buildings. For these three typologies, three projects were selected belonging to each municipality. Their basic characteristics (floor area, type of structure, façade, concrete slab, height from floor to ceiling and wall-to-wall width) are listed in Table 3 and their projects' bills of quantities can be found in Table 4 . All projects have one floor, concrete pads foundation, and sloped roof with portico support. 


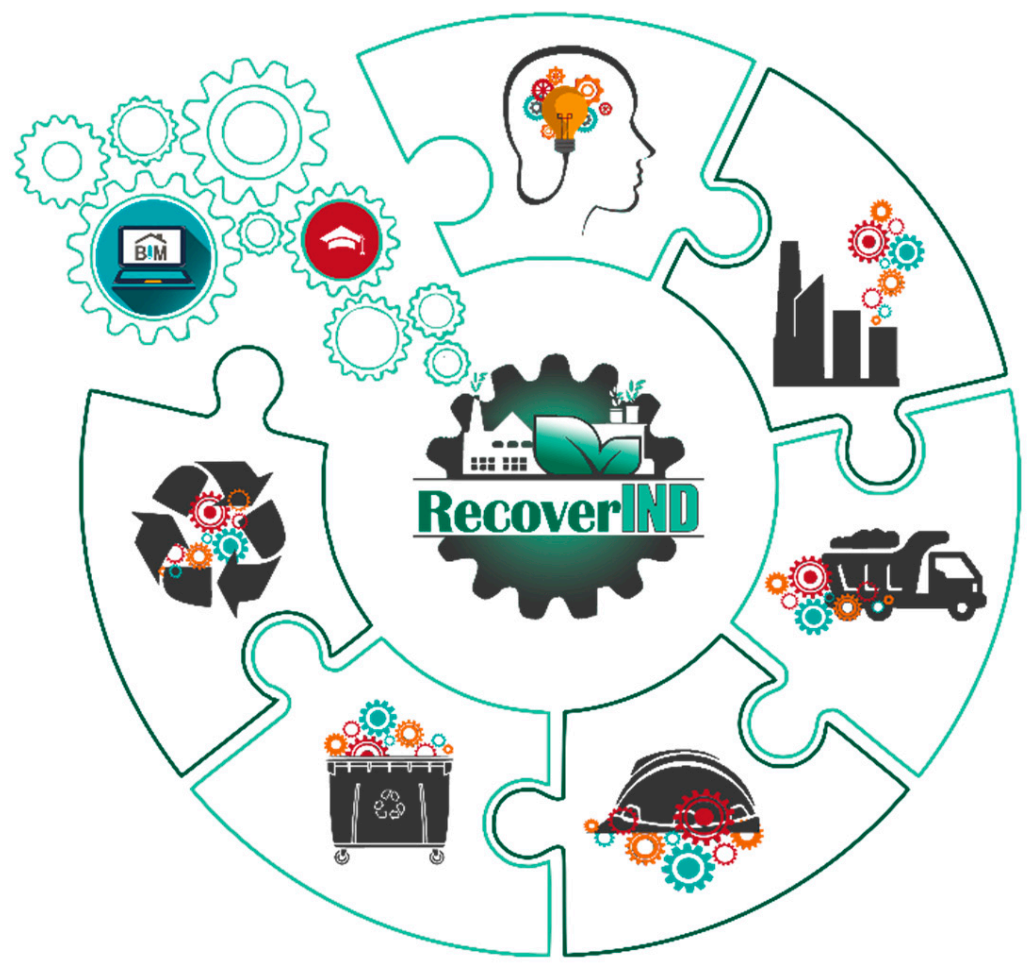

Figure 5. Homepage with the RecoverIND website menu for teaching tools [66].

Table 4. Bills of quantities of the three case studies according to the systematic classification defined in Table A1.

\begin{tabular}{|c|c|c|c|c|c|}
\hline Code & Unit & Description & N1 & N2 & N3 \\
\hline 02 & & EARTH WORK & & & \\
\hline 02EX & $\mathrm{m}^{3}$ & Open excavation & 0.09 & 1.17 & 0.10 \\
\hline 02RR & $\mathrm{m}^{3}$ & Refilling and compacting & & & 0.00 \\
\hline $02 \mathrm{TX}$ & $\mathrm{m}^{3}$ & Transport & 0.11 & 0.22 & 0.13 \\
\hline 03 & & FOUNDATION & & & \\
\hline 03AX & $\mathrm{kg}$ & Rebars & 15.70 & 0.65 & 3.99 \\
\hline 03EX & $\mathrm{m}^{2}$ & Formwork & & 0.36 & \\
\hline $03 \mathrm{HA}$ & $\mathrm{m}^{3}$ & Reinforced concrete & 0.07 & 0.11 & 0.09 \\
\hline 03HM & $\mathrm{m}^{3}$ & Bulk concrete & 0.01 & 0.17 & 0.01 \\
\hline 04 & & SEWAGE & & & \\
\hline 04EA & $\mathrm{u}$ & Manholes and pits & 0.01 & 0.03 & 0.01 \\
\hline 04EC & $\mathrm{m}$ & Underground pipeline & 0.12 & 0.16 & 0.04 \\
\hline 04VB & $\mathrm{m}$ & Vertical pipelines & 0.08 & 0.08 & 0.02 \\
\hline 05 & & STRUCTURE & & & \\
\hline 05AC & $\mathrm{kg}$ & Hot rolled steel & & 4.11 & 19.55 \\
\hline 05AF & $\mathrm{Kg}$ & Cold rolled steel & & & 5.66 \\
\hline 05FX & $\mathrm{m}^{2}$ & Concrete slab & & 1.03 & \\
\hline 05HA & $\mathrm{kg}$ & Steel rebar & & & 0.69 \\
\hline 06 & & BRICK WORK & & & \\
\hline 06BZ & $\mathrm{m}^{2}$ & Wall made of concrete blocks & & & 0.61 \\
\hline $06 \mathrm{PH}$ & $\mathrm{m}^{2}$ & Precast concrete & 1.28 & 2.19 & \\
\hline 07 & & ROOF & & & \\
\hline 07IX & $\mathrm{m}^{2}$ & Sloping roof & 0.79 & 0.93 & 0.93 \\
\hline
\end{tabular}


Table 4. Cont.

\begin{tabular}{|c|c|c|c|c|c|}
\hline Code & Unit & Description & N1 & $\mathrm{N} 2$ & N3 \\
\hline 08 & & INSTALLATIONS & & & \\
\hline 08EC & $\mathrm{m}$ & Electric circuits & 0.09 & & 0.35 \\
\hline 08ED & $\mathrm{m}$ & Electric bypass & 0.06 & 0.01 & \\
\hline 08EL & $\mathrm{u}$ & Lights & 0.01 & & 0.07 \\
\hline 08ET & $\mathrm{u}$ & Electric socket & 0.02 & & 0.05 \\
\hline 08EP & $\mathrm{m}$ & Grounding conductor & 0.00 & 0.38 & \\
\hline $08 \mathrm{FF}$ & $\mathrm{m}$ & Water pipes & & 0.01 & 0.10 \\
\hline 08FS & $\mathrm{u}$ & Bathroom sanitary ware & 0.00 & 0.01 & \\
\hline 10 & & FINISHES & & & \\
\hline $10 \mathrm{AA}$ & $\mathrm{m}^{2}$ & Tiles & 0.02 & & \\
\hline $10 S C$ & $\mathrm{~m}^{2}$ & Ceramic floor & 0.00 & & \\
\hline $10 S Y$ & $\mathrm{~m}^{2}$ & Medium weight floor & 0.99 & & \\
\hline $10 S Z$ & $\mathrm{~m}^{2}$ & High weight floor & & 1.00 & 0.20 \\
\hline $10 R X$ & $\mathrm{~m}$ & Windowsill & & & 0.02 \\
\hline 11 & & CARPENTRY AND SAFETY & & & \\
\hline $11 \mathrm{AX}$ & $\mathrm{m}^{2}$ & Steel & 0.00 & 0.07 & 0.03 \\
\hline $11 \mathrm{LX}$ & $\mathrm{m}^{2}$ & Aluminium & & 0.07 & 0.07 \\
\hline 12 & & GLASS AND POLYESTER & & & \\
\hline $12 X X$ & $\mathrm{~m}^{2}$ & Glass & & & 0.03 \\
\hline 13 & & PAINT & & & \\
\hline 13EX & $\mathrm{m}^{2}$ & Exterior & & & 0.02 \\
\hline 13IX & $\mathrm{m}^{2}$ & Interior & & 0.15 & \\
\hline
\end{tabular}

\section{Results and Discussion}

Table 5 shows the results obtained from the evaluation material consumption for the case studies. The project construction units and its quantities are grouped by families of materials according to their nature; the family of concrete and cement, used in the foundation and enclosures, having the highest consumption in terms of weight. The next families in terms of weight are aggregates and stones, used in the preparation of mortars and for the improvement of soil, and metals and alloys consumed in the structure, roof and installations. The most important families are similar to the ones employed in dwelling construction in Spain [67], except for the use of bricks and ceramic materials which are typical of the residential sector.

Table 5. Weight of construction materials consumed in the case studies grouped by family.

\begin{tabular}{|c|c|c|c|c|c|c|}
\hline Material Family & N1 (kg) & $\mathrm{N} 1\left(\mathrm{~kg} / \mathrm{m}^{2}\right)$ & N2 (kg) & N2 $\left(\mathrm{kg} / \mathrm{m}^{2}\right)$ & N3 (kg) & N3 $\left(\mathrm{kg} / \mathrm{m}^{2}\right)$ \\
\hline Concrete and cement & 927,550 & 1177.2 & 739,335 & 1591.8 & 952,434 & 1413.3 \\
\hline Ceramic and bricks & 9776 & 12.4 & 5763 & 12.4 & 8361 & 12.4 \\
\hline Wood & 3990 & 5.0 & 3342 & 7.1 & 2533 & 3.7 \\
\hline Metals and alloys & 41,755 & 52.9 & 16,865 & 36.3 & 32,788 & 48.6 \\
\hline Plastics & 2649 & 3.3 & 4079 & 8.7 & 3166 & 4.6 \\
\hline Water & 6007 & 7.6 & 5885 & 12.6 & 3137 & 4.6 \\
\hline Aggregates and stones & 271,077 & 344.0 & 181,726 & 391.2 & 209,129 & 310.3 \\
\hline Others & 36,223 & 45.9 & 25546 & 55.0 & 36,808 & 54.6 \\
\hline TOTAL & $1,299,031$ & 1648.7 & 982,543 & 2115.5 & $1,248,359$ & 1.852 .5 \\
\hline
\end{tabular}

Table 6 shows the results obtained from the environmental evaluation of the case studies. Since the N3 project was originally designed with a concrete block enclosure, a low percentage of recyclability can be obtained. For this reason, it was decided to evaluate the same project replacing the facade with precast concrete (as in cases N1 and N2). The results obtained show that not only is it possible to double the percentage of recyclability of the 
project, but also to reduce its environmental and economic impact. The labor required for the assembly of the prefabricated façade is reduced; however, more hours of machinery are required.

Table 6. Economic and environmental evaluation of the case studies.

\begin{tabular}{lrrrr}
\hline \multicolumn{1}{c}{ Project } & N1 & N2 & $\begin{array}{r}\text { N3 (Concrete } \\
\text { Block) }\end{array}$ & $\begin{array}{r}\text { N3 (Precast } \\
\text { Concrete) }\end{array}$ \\
\hline Budget $(€)$ & 181,623 & 137,964 & 208,182 & 190,879 \\
Cost per floor area $\left(€ / \mathrm{m}^{2}\right)$ & 230.52 & 297.05 & 308.93 & 283.25 \\
Carbon footprint $\left(\mathrm{tCO}_{2} \mathrm{eq}\right)$ & 271.36 & 204.043 & 234.949 & 232,442 \\
Carbon footprint $\left(\mathrm{tCO}_{2} \mathrm{eq} / \mathrm{m}^{2}\right)$ & 0.34 & 0.44 & 0.349 & 0.35 \\
Water footprint $\left(\mathrm{m}^{3}\right)$ & 8423 & 6778 & 7407 & 7,62 \\
Water footprint $\left(\mathrm{m}^{3} / \mathrm{m}^{2}\right)$ & 10.69 & 14.60 & 10.992 & 11.30 \\
CDW $(\mathrm{t}$ total) & 39,399 & 29,79 & 37,870 & 34,39 \\
CDW $\left(\mathrm{t}\right.$ total $\left./ \mathrm{m}^{2}\right)$ & 50.01 & 64.15 & 56.198 & 50.97 \\
\% Recyclability of raw materials & 64.15 & 64.12 & 34.89 & 64,31 \\
\% Recyclability of CDW & 49.88 & 49.19 & 49.58 & 49,37 \\
Total working hours & 3618 & 2972 & 3336 & 3095 \\
Total machine working hours & 354.72 & 383.35 & 148.74 & 208.35 \\
\hline
\end{tabular}

In terms of WF, plastics are the most important family, followed by wooden materials, even though these are not the most consumed. The CF of concrete and cement is the highest, followed by metals and alloys, both being also the most consumed families.

Solís-Guzmán et al. [46] observed that dwelling construction on average generates $600 \mathrm{kgCO} 2 \mathrm{eq} / \mathrm{m}^{2}$ of floor area, double that of industrial buildings. In addition, the cost obtained in that study $\left(800 € / \mathrm{m}^{2}\right)$ was triple the results for the industrial case studies analyzed here. Ruiz-Perez et al. [30], determined the carbon footprint of two urbanization projects during the renovation of a city street with gardens. Their footprint was 141.2 and $256.5 \mathrm{kgCO} 2 \mathrm{eq} / \mathrm{m}^{2}$ of street area, respectively. The project costs were also calculated as 88.9 and $205.3 € / \mathrm{m}^{2}$ of street area, respectively. Thus, the results obtained for the studied industrial buildings were of the same magnitude and not significantly different from these. Compared to the results from Bonamente et al. [5], where the carbon footprint of the construction phase was between 252 and $468 \mathrm{kgCO} 2 \mathrm{eq} / \mathrm{m}^{2}$ for the four case studies they analyzed, those from the present study fall under that range, which can be explained by differences in the calculation method. Regarding the weight of materials consumption, several studies by Scheuer et al. [68], Kofoworola and Gheewala [69] and Tulevech et al. [6] have reported similar values for office, institutional and industrial buildings.

It is also of note that, in the case of dwelling construction, a standardized cost database was employed with all the representative data from social housing construction, while for that of urbanization and gardening, only the work classification system was available from open-source databases, but it was necessary to create new construction work units specifically for the two projects studied. In the case of industrial building construction, construction cost databases are not available, so it was necessary to adapt the classification system of dwelling construction to industrial buildings. Many similarities were found in several work units, such as those related to the building's installations, but others needed to be created anew.

In Table 6, the recyclability criteria are established as follows: concrete and cement (70\% in dry assembly and 40\% in wet solutions), ceramics and bricks (20\%), wood (30\%), metals $(100 \%)$, plastics $(0 \%)$, water $(0 \%)$, aggregates and stones $(50 \%$ in dry assembly and $30 \%$ in wet solutions), excavated soil is $80 \%$, and other materials $(10 \%)$. The total percentage of recyclability is obtained by dividing the total weight of recyclable materials or CDW by the total weight consumed or generated, respectively.

Another way of putting together the information is by chapters in the project budget, which represent stages in the construction work. As can be seen in Figure 6, the chapter of structures is the most impacting, followed by foundation, making these stages of the 
execution of the project crucial for controlling the environmental impact in terms of CF. The execution of the installations is shown to be an important factor regarding the WF indicator.

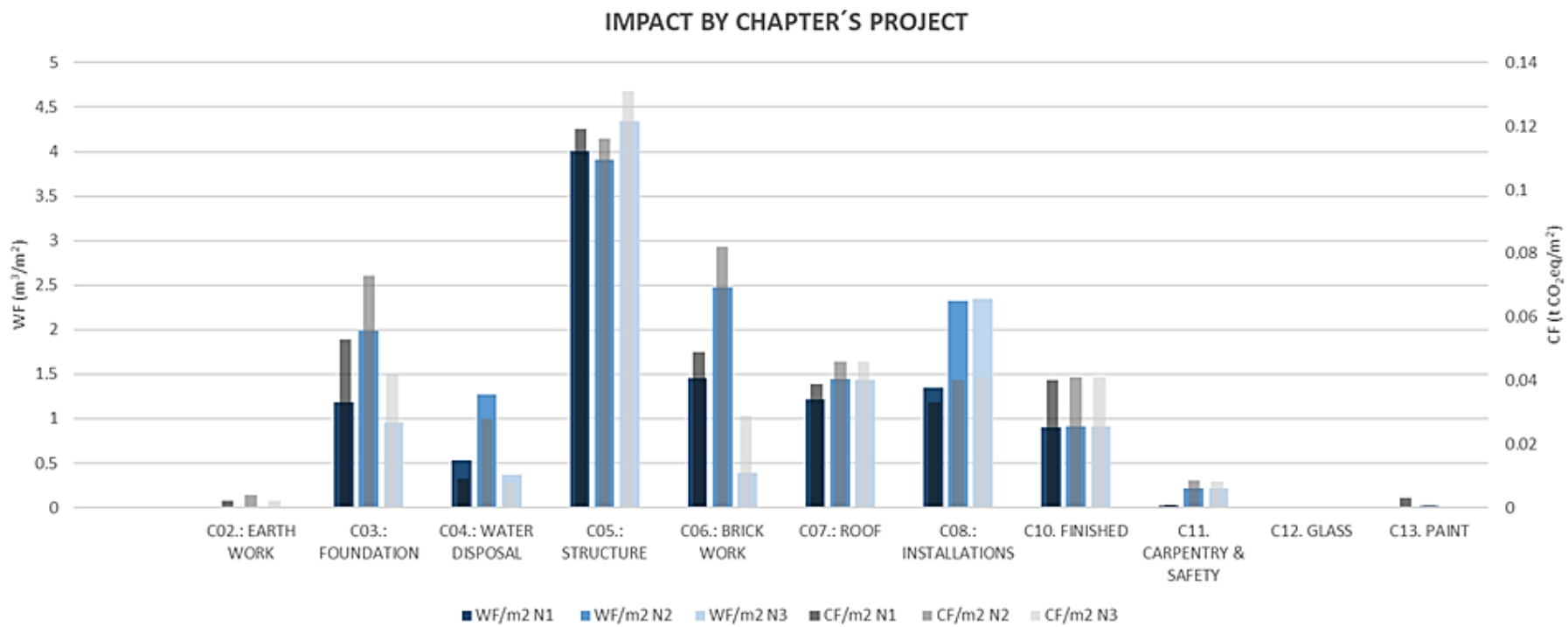

Figure 6. Carbon and water footprint of case studies per chapter of the classification system.

In Figure 7, these impacts are represented in percentages, clearly showing that almost half of the CF is caused by use of concrete and cement, and that the WF is controlled in a similar way by three families: concrete and cement, wood and plastics, representing about $70 \%$ of the total.

The CDW generated by the three projects is presented by family in Table 7 . As expected, the most consumed materials are also the ones that generate most of the waste, specifically the family of concrete and cement. This family has a high recycling potential, and elements can be reused if carefully extracted. The next family in importance is aggregates and stones, inert materials that can be recycled if not mixed with other materials. In Spain, since 2008, efforts have been made to recycle these by introducing recycled aggregates usage and control in the Code of Structural Concrete [70], but still less than $10 \%$ is used in new concrete, while the rest is mainly used as land refill [71]. However, recycled concrete can replace elements in construction that are less restrictive, such as cycling tracks, trench filling and electric shaft foundations [72]. In these applications it has been shown that in-situ recycling of concrete can generate significant savings [65].

Table 7. Weight of CDW in the case studies grouped by material family.

\begin{tabular}{|c|c|c|c|c|c|c|}
\hline Material Family & N1 (kg) & $\mathrm{N} 1\left(\mathrm{~kg} / \mathrm{m}^{2}\right)$ & N2 (kg) & $\mathrm{N} 2\left(\mathrm{~kg} / \mathrm{m}^{2}\right)$ & N3 (kg) & N3 $\left(\mathrm{kg} / \mathrm{m}^{2}\right)$ \\
\hline Concrete and cement & $27,826.514$ & 35.317 & $22,180.058$ & 47.756 & $28,573.022$ & 42.401 \\
\hline Ceramic and bricks & 586.596 & 0.745 & 345.785 & 0.745 & 501.707 & 0.745 \\
\hline Wood & 199.542 & 0.253 & 167.103 & 0.360 & 126.687 & 0.188 \\
\hline Metals and alloys & 1252.661 & 1.590 & 505.958 & 1.089 & 983.653 & 1.460 \\
\hline Plastics & 132.464 & 0.168 & 203.986 & 0.439 & 158.304 & 0.235 \\
\hline Water & 147.337 & 0.187 & 173.704 & 0.374 & 148.927 & 0.221 \\
\hline Aggregates and stones & 8132.319 & 10.322 & 5451.782 & 11.738 & 6273.879 & 9.310 \\
\hline Others & 1086.720 & 1.379 & 766.389 & 1.650 & 9.310 & 1.639 \\
\hline TOTAL & $39,364.153$ & 49.961 & $29,794.765$ & 64.151 & $36,775.490$ & 56.198 \\
\hline
\end{tabular}



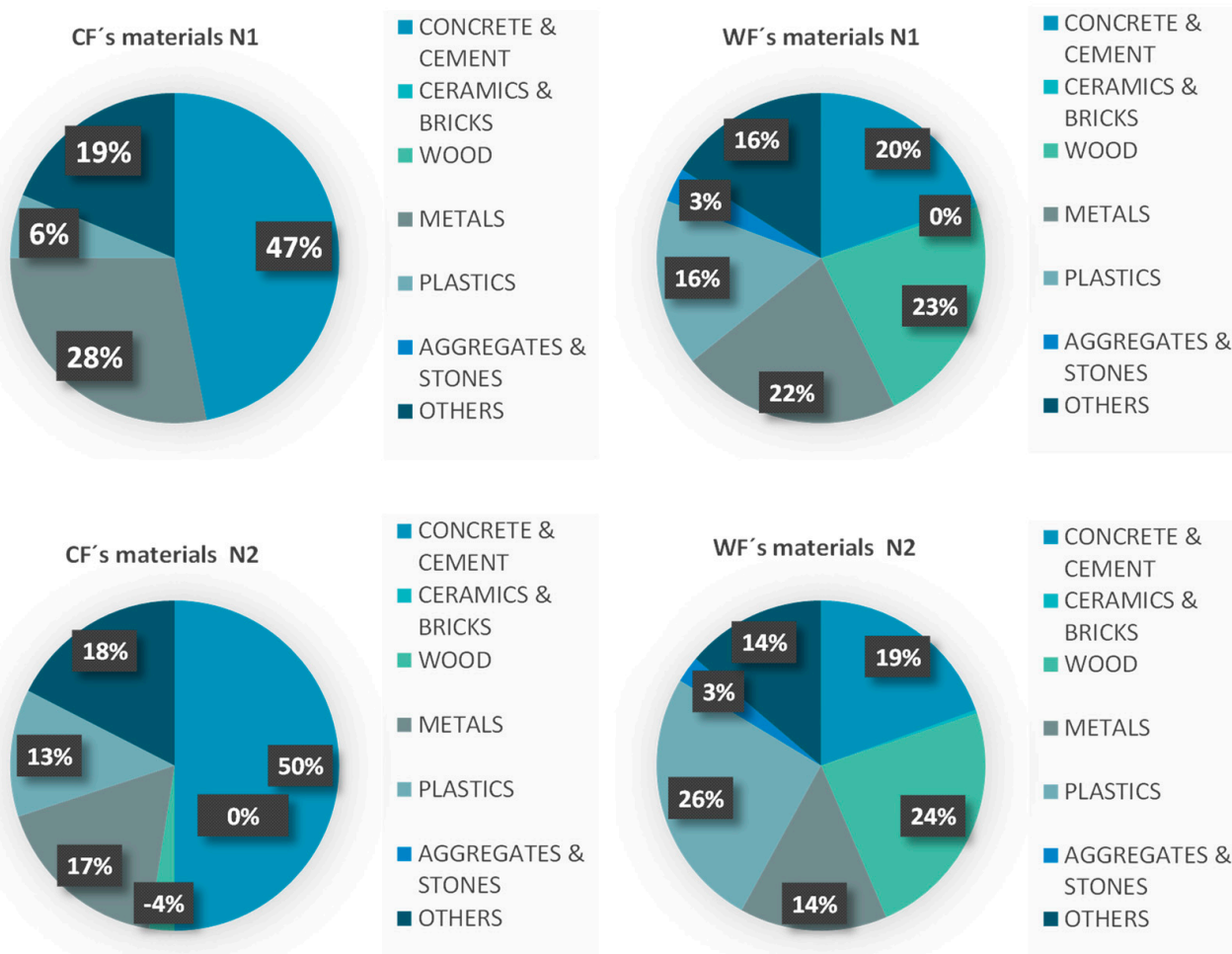

CONCRETE \&
CEMENT
CERAMICS \&
BRICKS
WOOD
METALS
PLASTICS
AGGREGATES \&
STONES
OTHERS

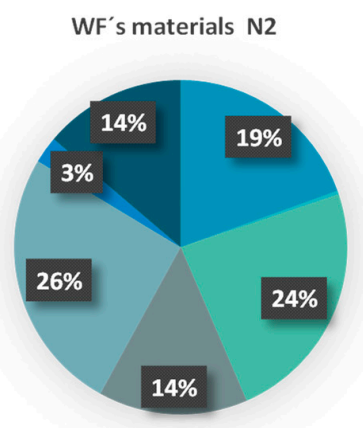

CONCRETE \&
CEMENT
CERAMICS \&
BRICKS
WOOD
METALS
PLASTICS
AGGREGATES \&
STONES
OTHERS
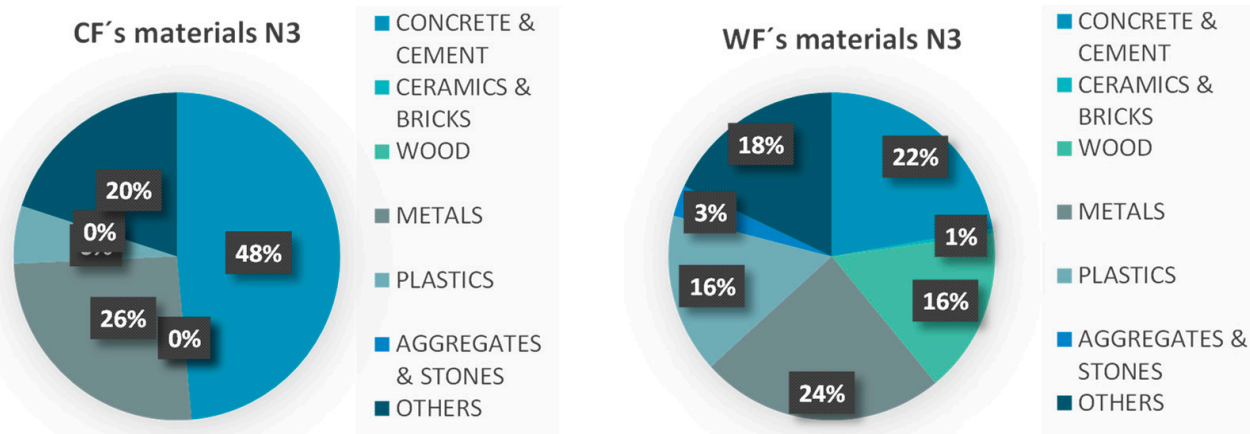

Figure 7. Carbon and water footprint of case studies by material family.

\section{Conclusions}

A structured and straightforward methodology is proposed for the evaluation of industrial buildings construction. The analysis starts with the evaluation of typical or most representative constructions in the area of study. A survey is proposed for the data collection based on construction cost classification. All this allows an easy comparison with other types of buildings. However, the most consumed material is not always the most impacting. That is the case for stones and aggregates in terms of CF. Furthermore, materials with a low consumption, such as the plastics family, has a high WF. The most impacting materials in both CF and WF indicators are cement and concrete, as expected. The second most impacting is the family of metals and alloys, used not only in the structure but also in the roof and installations.

The waste generated in the projects is also calculated. This is mainly inert material, such as concrete and cement or aggregates and stones. The non-hazardous materials employed have a high recycling or reuse potential, which is the case for metallic roofs and structure.

Due to the identified high recycling potential, it is recommended that future research includes evaluation of the building's life cycle and its recycling/reusing potential, since 
these buildings have a short service life of 35 years according to Spanish legislation. The assessment can also be implemented in future work in building information modeling.

Author Contributions: Conceptualization, M.M. and C.R.-C.; methodology, M.D.A.-R.; software, C.R.-C.; validation, C.R.-C., M.M. and J.S.-G.; formal analysis, A.M.-R.; investigation, J.S.-G.; resources, J.S.-G.; data curation, J.S.-G.; writing—original draft preparation, M.M.; writing-review and editing, A.M.-R.; visualization, M.D.A.-R.; supervision, M.M.; project administration, M.M.; funding acquisition, M.M. All authors have read and agreed to the published version of the manuscript.

Funding: This work is partially funded by the RECOVERIND project (2020-1-RO01-KA203-080223), an ERASMUS+ project co-funded by the European Union and within the framework of an initiative of 2020 (KA2, Strategic partnerships in the field of higher education), with the support of the Servicio Español Para la Internacionalización de la Educación (SEPIE, Spain), and by the VI Own Research and Knowledge Transfer Plan of the University of Seville (VI-PPIT US).

Conflicts of Interest: The authors declare no conflict of interest. The funders had no role in the design of the study; in the collection, analyses, or interpretation of data; in the writing of the manuscript, or in the decision to publish the results. The European Commission's support for the production of this publication does not constitute an endorsement of the contents, which reflect the views only of the authors, and the Commission cannot be held responsible for any use which may be made of the information contained therein.

\section{Appendix A}

Table A1. New classification model for industrial building projects based on the ACCD.

\begin{tabular}{|c|c|c|}
\hline Code & Unit & Description \\
\hline 02 & & EARTH WORK \\
\hline 02EX & $\mathrm{m}^{3}$ & Open excavation \\
\hline 02RR & $\mathrm{m}^{3}$ & Refilling and compacting \\
\hline 02TX & $\mathrm{m}^{3}$ & Transport \\
\hline 03 & & FOUNDATION \\
\hline 03AX & $\mathrm{kg}$ & Rebars \\
\hline 03СР & $\mathrm{m}$ & Piles \\
\hline 03EX & $\mathrm{m}^{2}$ & Formwork \\
\hline 03HA & $\mathrm{m}^{3}$ & Reinforced concrete \\
\hline 03HМ & $\mathrm{m}^{3}$ & Bulk concrete \\
\hline 04 & & SEWAGE \\
\hline 04EA & $\mathrm{u}$ & Manholes and pits \\
\hline 04EC & $\mathrm{m}$ & Underground pipeline \\
\hline 04VB & $\mathrm{m}$ & Vertical pipelines \\
\hline 05 & & STRUCTURE \\
\hline 05AC & $\mathrm{kg}$ & Hot rolled steel \\
\hline $05 \mathrm{AF}$ & $\mathrm{Kg}$ & Cold rolled steel \\
\hline 05FX & $\mathrm{m}^{2}$ & Concrete slab \\
\hline 05HA & $\mathrm{kg}$ & Steel rebar \\
\hline 05HE & $\mathrm{m}^{2}$ & Formwork \\
\hline $05 \mathrm{HH}$ & $\mathrm{m}^{3}$ & Reinforced concrete \\
\hline 05MX & $\mathrm{m}^{3}$ & Structure wood \\
\hline 06 & & BRICK WORK \\
\hline 06BZ & $\mathrm{m}^{2}$ & Wall made of concrete blocks \\
\hline 06DX & $\mathrm{m}^{2}$ & Chamber wall made with bricks \\
\hline 06DY & $\mathrm{m}^{2}$ & Partitions made with bricks \\
\hline 06LX & $\mathrm{m}^{2}$ & Brick exterior wall \\
\hline 06LY & $\mathrm{m}^{2}$ & Brick interior wall \\
\hline 06LZ & $\mathrm{m}^{2}$ & Masonry walls \\
\hline 06PA & $\mathrm{m}^{2}$ & Metal precast \\
\hline 06PH & $\mathrm{m}^{2}$ & Precast concrete \\
\hline
\end{tabular}


Table A1. Cont.

\begin{tabular}{|c|c|c|}
\hline Code & Unit & Description \\
\hline 07 & & ROOF \\
\hline 07HX & $\mathrm{m}^{2}$ & Horizontal roof \\
\hline 07IX & $\mathrm{m}^{2}$ & Sloping roof \\
\hline 08 & & INSTALLATIONS \\
\hline 08CA & $\mathrm{u}$ & Air conditioning and hot water \\
\hline $08 \mathrm{CC}$ & $\mathrm{m}$ & Air conditioning ducts \\
\hline 08EC & $\mathrm{m}$ & Electric circuits \\
\hline 08ED & $\mathrm{m}$ & Electric bypass \\
\hline 08EL & $\mathrm{u}$ & Lights \\
\hline 08ET & $\mathrm{u}$ & Electric socket \\
\hline 08EP & $\mathrm{m}$ & Grounding conductor \\
\hline 08FF & $\mathrm{m}$ & Water pipes \\
\hline 08FS & $\mathrm{u}$ & Bathroom sanitary ware \\
\hline 09 & & INSULATION \\
\hline 09AX & $\mathrm{m}^{2}$ & Acoustic \\
\hline 09TX & $\mathrm{m}^{2}$ & Thermal \\
\hline 10 & & FINISHES \\
\hline $10 \mathrm{AA}$ & $\mathrm{m}^{2}$ & Tiles \\
\hline $10 \mathrm{AC}$ & $\mathrm{m}^{2}$ & Front plates \\
\hline $10 \mathrm{CE}$ & $\mathrm{m}^{2}$ & Continuous \\
\hline $10 C G$ & $\mathrm{~m}^{2}$ & Continuous light weight \\
\hline $10 \mathrm{SC}$ & $\mathrm{m}^{2}$ & Ceramic floor \\
\hline $10 \mathrm{SN}$ & $\mathrm{m}^{2}$ & Natural stone floor \\
\hline $10 S X$ & $\mathrm{~m}^{2}$ & Light weight floor \\
\hline $10 S Y$ & $\mathrm{~m}^{2}$ & Medium weight floor \\
\hline $10 S Z$ & $\mathrm{~m}^{2}$ & High weight floor \\
\hline $10 \mathrm{TX}$ & $\mathrm{m}^{2}$ & Ceiling \\
\hline $10 \mathrm{RX}$ & $\mathrm{m}$ & Windowsill \\
\hline 11 & & CARPENTRY AND SAFETY \\
\hline $11 \mathrm{AX}$ & $\mathrm{m}^{2}$ & Steel \\
\hline $11 \mathrm{LX}$ & $\mathrm{m}^{2}$ & Aluminum \\
\hline $11 \mathrm{MX}$ & $\mathrm{m}^{2}$ & Wood \\
\hline 12 & & GLASS AND POLYESTER \\
\hline $12 X X$ & $\mathrm{~m}^{2}$ & Glass \\
\hline 13 & & PAINT \\
\hline 13EX & $\mathrm{m}^{2}$ & Exterior \\
\hline 13IX & $\mathrm{m}^{2}$ & Interior \\
\hline
\end{tabular}

\section{References}

1. United Nations UN General Assembly Resolution on The Future we Want (Adopted on 27 July 2012); UN General Assembly: Rio de Janeiro, Brazil, 2012; pp. 1-53.

2. Renukappa, S.; Akintoye, A.; Egbu, C.; Suresh, S. Sustainable procurement strategies for competitive advantage: An empirical study. Proc. Inst. Civ. Eng.-Manag. Procure. Law 2016, 169, 17-25. [CrossRef]

3. San-José Lombera, J.T.; Garrucho Aprea, I. A system approach to the environmental analysis of industrial buildings. Build. Environ. 2010, 45, 673-683. [CrossRef]

4. San-José Lombera, J.T.; Cuadrado Rojo, J. Industrial building design stage based on a system approach to their environmental sustainability. Constr. Build. Mater. 2010, 24, 438-447. [CrossRef]

5. Bonamente, E.; Cotana, F. Carbon and energy footprints of prefabricated industrial buildings: A systematic life cycle assessment analysis. Energies 2015, 8, 12685-12701. [CrossRef]

6. Tulevech, S.M.; Hage, D.J.; Jorgensen, S.K.; Guensler, C.L.; Himmler, R.; Gheewala, S.H. Life cycle assessment: A multi-scenario case study of a low-energy industrial building in Thailand. Energy Build. 2018, 168, 191-200. [CrossRef]

7. Opher, T.; Duhamel, M.; Posen, I.D.; Panesar, D.K.; Brugmann, R.; Roy, A.; Zizzo, R.; Sequeira, L.; Anvari, A.; MacLean, H.L. Life cycle GHG assessment of a building restoration: Case study of a heritage industrial building in Toronto, Canada. J. Clean. Prod. 2021, 279, 123819. [CrossRef] 
8. Shubbar, A.; Nasr, M.; Falah, M.; Al-Khafaji, Z. Towards net zero carbon economy: Improving the sustainability of existing industrial infrastructures in the uk. Energies 2021, 14, 5896. [CrossRef]

9. Heravi, G.; Fathi, M.; Faeghi, S. Evaluation of sustainability indicators of industrial buildings focused on petrochemical projects J. Clean. Prod. 2015, 109, 92-107. [CrossRef]

10. Židoniene, S.; Kruopiene, J. Life Cycle Assessment in environmental impact assessments of industrial projects: Towards the improvement. J. Clean. Prod. 2015, 106, 533-540. [CrossRef]

11. Kovacic, I.; Waltenbereger, L.; Gourlis, G. Tool for life cycle analysis of facade-systems for industrial buildings. J. Clean. Prod. 2016, 130, 260-272. [CrossRef]

12. Švajlenka, J.; Kozlovská, M.; Pošiváková, T. Analysis of selected building constructions used in industrial construction in terms of sustainability benefits. Sustainability 2018, 10, 4394. [CrossRef]

13. Aye, L.; Ngo, T.; Crawford, R.H.; Gammampila, R.; Mendis, P. Life cycle greenhouse gas emissions and energy analysis of prefabricated reusable building modules. Energy Build. 2012, 47, 159-168. [CrossRef]

14. Begum, R.A.; Satari, S.K.; Pereira, J.J. Waste Generation and Recycling: Comparison of Conventional and Industrialized Building Systems. Am. J. Environ. Sci. 2010, 6, 383-388. [CrossRef]

15. Jaillon, L.; Poon, C.S.; Chiang, Y.H. Quantifying the waste reduction potential of using prefabrication in building construction in Hong Kong. Waste Manag. 2009, 29, 309-320. [CrossRef] [PubMed]

16. Li, Z.; Shen, G.Q.; Alshawi, M. Measuring the impact of prefabrication on construction waste reduction: An empirical study in China. Resour. Conserv. Recycl. 2014, 91, 27-39. [CrossRef]

17. Lu, W.; Lee, W.M.W.; Xue, F.; Xu, J. Revisiting the effects of prefabrication on construction waste minimization: A quantitative study using bigger data. Resour. Conserv. Recycl. 2021, 170, 105579. [CrossRef]

18. Mah, C.M.; Fujiwara, T.; Ho, C.S. Environmental impacts of construction and demolition waste management alternatives. Chem. Eng. Trans. 2018, 63, 343-348. [CrossRef]

19. Lützkendorf, T. Sustainability in Building Construction-A Multilevel Approach. Junio 2019. In Proceedings of the IOP Conference Series: Earth and Environmental Science, Prague, Czech Republic, 2-4 July 2019; Volume 290.

20. International Organization for Standardization. ISO 14040; Environmental Management, Life Cycle Assessment, Principles and Framework. ISO: Geneva, Switzerland, 2006.

21. International Organization for Standardization. ISO 14044; Environmental Management, Life Cycle Assessment, Requirements and Guidelines. ISO: Geneva, Switzerland, 2006.

22. LPSC_9/2017 Law 9/2017 of 8 November, on Public Sector Contracts, which Transposes into Spanish Law the Directives of the European Parliament and Council 2014/23/EU and 2014/24/EU, of 26 February 2014; Government of Spain: Madrid, Spain, 2017.

23. Orden, P.C.I. 86/2019, de 31 de Enero, por la que se Publica el Acuerdo del Consejo de Ministros de 7 de diciembre de 2018, por el que se Aprueba el Plan de Contratación Pública Ecológica de la Administración General del Estado, sus Organismos Autónomos; $2019 ;$ pp. 9572-9597. Available online: https:/ / www.boe.es/diario_boe/txt.php?id=BOE-A-2019-1394 (accessed on 24 November 2021). (In Spanish)

24. BREEAM BREEAM International New Construction 2016, Technical Manual, Version: SD233 2.0. Available online: https: / / tools.breeam.com/filelibrary/TechnicalManuals/BREEAM_International_NC_2016_Technical_Manual_2.0.pdf (accessed on 15 December 2021).

25. SpainGBC LEED en España 2015. Available online: http://www.spaingbc.org/web/detalle-noticia.php?id=91 (accessed on 15 December 2021)

26. Ecómetro Association Ecómetro. Association for the Measurement and Diffusion of Ecology in Architecture. Available online: http:/ / ecometro.org/ (accessed on 15 December 2021).

27. ITeC Construction Cost Database (BEDEC). Available online: https://itec.es/servicios/bedec/?gclid=EAIaIQobChMI57HB4 MTm9AIVlfhRCh1wdwThEAAYASAAEgI8OPD_BwE (accessed on 30 November 2021).

28. SOFIA Situated learning Opportunities Fostered by ICT Applications in Alternative Agro-Food Networks (SOFIA). Available online: https:/ / cordis.europa.eu/project/id/702884 (accessed on 30 November 2021).

29. e2CO2cero Software to calculate the Embodied Energy and Carbon Footprint of buildings in a simple way. Available online: http:/ / online.e2co2cero.com/ (accessed on 15 December 2021).

30. Ruiz-Pérez, M.R.; Alba-Rodríguez, M.D.; Rivero-Camacho, C.; Solís-Guzmán, J.; Marrero, M. The budget as a basis for ecological management of urbanization projects. Case study in Seville, Spain. Sustainability 2021, 13, 4078. [CrossRef]

31. INE Encuesta Industrial de Empresas. Serie 2008-2014. CNAE-2009. Número de Empresas por Sectores de Actividad. Available online: https:/ / www.ine.es/jaxiT3/Datos.htm?t=2539 (accessed on 24 November 2021).

32. Freire-Guerrero, A.; Alba-Rodríguez, M.D.; Marrero, M. A budget for the ecological footprint of buildings is possible: A case study using the dwelling construction cost database of Andalusia. Sustain. Cities Soc. 2019, 51, 101737. [CrossRef]

33. Marrero, M.; Wojtasiewicz, M.; Martínez-Rocamora, A.; Solís-Guzmán, J.; Alba-Rodríguez, M.D. BIM-LCA integration for the environmental impact assessment of the urbanization process. Sustainability 2020, 12, 4196. [CrossRef]

34. Marrero, M.; Rivero-Camacho, C.; Alba-Rodríguez, M.D. What are we discarding during the life cycle of a building? Case studies of social housing in Andalusia, Spain. Waste Manag. 2020, 102, 391-403. [CrossRef]

35. Construction Specifications Institute/Construction Specifications Canada (CSI/CSC). Masterformat Manual of Practice (MP2-1), Construction Specifications Institute: Alexandria, VA, USA; Construction Specifications Canada: Toronto, ON, Canada, 1983.

36. Jones, A.R. CI/SfB Construction Indexing Manual; RIBA Publishing: London, UK, 1987. 
37. Telford, T. Civil Engineering Standard Method of Measurement, 3rd ed.; The Institution of Civil Engineers and The Federation of Civil Engineering Contractors: London, UK, 1991; pp. 4-39.

38. UniFormat ${ }^{\mathrm{TM}}$ A Uniform Classification of Construction Systems and Assemblies; The Construction Specifications Institute: Alexandria, VA, USA, 1998.

39. Omniclass. Omniclass ${ }^{\mathrm{TM}}$ : A Strategy for Classifying the Built Environment-Table 13: Spaces by Function; The Construction Specifications Institute: Alexandria, VA, USA, 2012.

40. Marrero, M.; Ramirez-de-Arellano, A. The building cost system in Andalusia: Application to construction and demolition waste management. Constr. Manag. Econ. 2010, 28, 495-507. [CrossRef]

41. Ministry of Development and Housing Andalusian Construction Cost Database (ACCD). Available online: https://www juntadeandalucia.es/organismos/fomentoinfraestructurasyordenaciondelterritorio/areas/vivienda-rehabilitacion/planesinstrumentos / paginas/bcca-sept-2017.html (accessed on 30 November 2021).

42. Alba-Rodríguez, M.D.; Machete, R.; Glória Gomes, M.; Paula Falcão, A.; Marrero, M. Holistic model for the assessment of restoration projects of heritage housing. Case studies in Lisbon. Sustain. Cities Soc. 2021, 67, 102742. [CrossRef]

43. Cabeza, L.F.; Rincón, L.; Vilariño, V.; Pérez, G.; Castell, A. Life cycle assessment (LCA) and life cycle energy analysis (LCEA) of buildings and the building sector: A review. Renew. Sustain. Energy Rev. 2014, 29, 394-416. [CrossRef]

44. Freire Guerrero, A.; Marrero Meléndez, M.; Muñoz Martín, J. Incorporación de huella de carbono y huella ecológica en las bases de costes de construcción. Estudio de caso de un proyecto de urbanización en Écija, España. Hábitat Sustentable 2016, 6, 6-17. (In Spanish) [CrossRef]

45. Solís-Guzmán, J.; Martínez-Rocamora, A.; Marrero, M. Methodology for Determining the Carbon Footprint of the Construction of Residential Buildings; Springer: Singapore, 2014; pp. 49-83.

46. Solís-Guzmán, J.; Rivero-Camacho, C.; Alba-Rodríguez, D.; Martínez-Rocamora, A. Carbon Footprint Estimation Tool for Residential Buildings for Non-Specialized Users: OERCO2 Project. Sustainability 2018, 10, 1359. [CrossRef]

47. Chastas, P.; Theodosiou, T.; Kontoleon, K.J.; Bikas, D. Normalising and assessing carbon emissions in the building sector: A review on the embodied CO 2 emissions of residential buildings. Build. Environ. 2018, 130, 212-226. [CrossRef]

48. Ruiz-Pérez, M.R.; Alba Rodríguez, M.D.; Marrero, M. Systems of Water Supply and Sanitation for Domestic Use. In Proceedings of the Water Footprint and Carbon Footprint Evaluation: First Results; IV International Congress on Construction and Building Research—Santa Cruz de Tenerife, Tenerife, Spain, 14-15 December 2017.

49. Ruiz-Pérez, M.R.; Alba-Rodríguez, M.D.; Marrero, M. The water footprint of city naturalisation. Evaluation of the water balance of city gardens. In Proceedings of the 22nd biennial conference of The International Society for Ecological Modelling (ISEM), Salzburg, Austria, 30 September-4 October 2019.

50. WFN Water Footprint Network. Available online: https://waterfootprint.org/en/ (accessed on 15 December 2021).

51. Hoekstra, A.Y.; Chapagain, A.K.; Aldaya, M.M.; Mekonnen, M.M. Water Footprint Manual: State of the Art 2009; Faculty of Engineering Technology, University of Twente: Enschede, The Netherlands, 2009.

52. Hoekstra, A.Y.; Chapagain, A.K.; Aldaya, M.M.; Mekonnen, M.M. The Water Footprint Assessment Manual; Routledge: Abingdonon-Thames, UK, 2011; ISBN 9781849712798.

53. Martínez-Rocamora, A.; Solís-Guzmán, J.; Marrero, M. LCA databases focused on construction materials: A review. Renew. Sustain. Energy Rev. 2016, 58, 565-573. [CrossRef]

54. ISO 15804:2012+A1:2013 Sustainability of Construction Works. Environmental Product Declarations. Core Rules for the Product Category of Construction Products; ISO: Geneva, Switzerland, 2012.

55. IDAE Factores de emisión de $\mathrm{CO}_{2} / \mathrm{CO}_{2}$ Emission Factors. Available online: http://www.idae.es/uploads/documentos/ documentos_Factores_Conversion_Energia_y_CO2_2011_0a9cb734.pdf (accessed on 4 August 2015).

56. REE Informe del Sistema Eléctrico Español 2020/Report on the Spanish Electricity System 2020. Available online: https://www.ree.es/es/datos/publicaciones/informe-anual-sistema/informe-del-sistema-electrico-espanol-2020 (accessed on 15 December 2021).

57. IDAE Factores de emisión de $\mathrm{CO}_{2}$ y coeficientes de paso a energía primaria de diferentes fuentes de energía final consumidas en el sector de edificios de España/ $\mathrm{CO}_{2}$ emission factors and transformation coefficients of different final energy sources consumed by. Available online: https:/ / energia.gob.es/desarrollo/EficienciaEnergetica/RITE/Reconocidos/Reconocidos/Otrosdocumentos/ Factores_emision_CO2.pdf (accessed on 15 December 2021). (In Spanish).

58. IETcc. Catálogo de Elementos Constructivos del CTE; Instituto Eduardo Torroja de Ciencias de la Construcción (IETcc): Madrid, Spain, 2010. (In Spanish)

59. Spanish Ministry of Housing. Royal Decree 314/2006 of 17 March 2006, Approving the Technical Building Code; Spanish Ministry of Housing: Madrid, Spain, 2006; ISBN 843401632X.

60. Frischknecht, R.; Jungbluth, N.; Althaus, H.-J.; Doka, G.; Dones, R.; Heck, T.; Hellweg, S.; Hischier, R.; Nemecek, T.; Rebitzer, G. The ecoinvent database: Overview and methodological framework (7 pp). Int. J. Life Cycle Assess. 2005, 10, 3-9. [CrossRef]

61. Ecoinvent Association Ecoinvent Database v3. Available online: http://www.ecoinvent.org/database/database.html (accessed on 28 March 2018)

62. REE. El Sistema Eléctrico Español/The Spanish Electric System; REE: Madrid, Spain, 2014.

63. Hoekstra, A.Y. Virtual water trade between nations: A global mechanism affecting regional water systems. IGBP Glob. Chang. News Lett. 2003, 54, 2-4. 
64. Solís-Guzmán, J.; Marrero, M.; Montes-Delgado, M.V.; Ramírez-de-Arellano, A. A Spanish model for quantification and management of construction waste. Waste Manag. 2009, 29, 2542-2548. [CrossRef]

65. Marrero, M.; Puerto, M.; Rivero-Camacho, C.; Freire-Guerrero, A.; Solís-Guzmán, J. Assessing the economic impact and ecological footprint of construction and demolition waste during the urbanization of rural land. Resour. Conserv. Recycl. 2017, 117, 160-174. [CrossRef]

66. UniTBv; US; RoGBC; CTM; Datacomp; FPiP; Poznan, P. Erasmus+ Project RecoverIND Website. Available online: www. recoverind.eu (accessed on 24 November 2021).

67. González-Vallejo, P.; Muntean, R.; Solís-Guzmán, J.; Marrero, M. Carbon footprint of dwelling construction in Romania and Spain. A comparative analysis with the OERCO2 tool. Sustainability 2020, 12, 6745. [CrossRef]

68. Scheuer, C.; Keoleian, G.A.; Reppe, P. Life cycle energy and environmental performance of a new university building: Modeling challenges and design implications. Energy Build. 2003, 35, 1049-1064. [CrossRef]

69. Kofoworola, O.F.; Gheewala, S.H. Life cycle energy assessment of a typical office building in Thailand. Energy Build. 2009, 41, 1076-1083. [CrossRef]

70. EHE. Real Decreto 1247/2008, de 18 de Julio, por el que se Aprueba la Instrucción de Hormigón Estructural (EHE-08). Royal Decree 1247/2008, of July 18, which Approves the Structural Concrete Instruction (EHE-08); 2008. Available online: https: / / www.boe.es / buscar/doc.php?id=BOE-A-2008-14167 (accessed on 24 November 2021). (In Spanish)

71. National Statistics Institute. Estadísticas Sobre la Recogida y Tratamiento de Residuos 2019; National Statistics Institute: Madrid, Spain, 2019. (In Spanish)

72. Redcicla Construcción/Construction. Available online: http:/ / www.redcicla.com/construccion.html (accessed on 15 December 2021). 